OmniAkuatika, 11 (2): 1-5, 2015
ISSN: 1858-3873 print / 2476-9347 online
Research Article

\title{
HEAVY METALS (Ni, Cu, Zn AND Cd) CONTENT IN SERUM OF RAT FED GREEN MUSSELS (Perna Viridis)
}

\author{
Muhammad Yudhistira Azis ${ }^{1,2}$, Suryo Gandasasmita ${ }^{1}$ dan Agung Dhamar Syakti ${ }^{2}$ \\ ${ }^{1}$ Analytical Chemistry Laboratory, Department of Chemistry, Institute of Technology Bandung, \\ Jl. Ganesha No. 10, Bandung 40132, Indonesia \\ ${ }^{3}$ Centre for Maritime Bioscience Studies-Institute for Research and Community Service, Jenderal Soedirman \\ University, Jl. Dr. Suparno, Purwokerto 53123, Indonesia \\ "Corresponding author: yudis_chempd@yahoo.com
}

\begin{abstract}
Green mussel (Perna viridis) can playing role as bio-indicator or biomonitoring agent for heavy-metal contaminations in the sea. In this research, the concentrations of four elements $\mathrm{Ni}, \mathrm{Cu}, \mathrm{Zn}$ and $\mathrm{Cd}$ in $P$. viridis and in the serum of rat which orally feed by $P$. viridis were determined by Atomic Absorption Spectrometry (AAS) following dry acid digestion. Parameter analysis was evaluated by determining confidence limit for the obtained results. The result showed that there was a sequence of heavy-metal content in green mussels sample and laboratory rats serum, such as $\mathrm{Ni}<\mathrm{Cd}<\mathrm{Cu}<\mathrm{Zn}$.
\end{abstract}

Keywords: heavy metals, green mussels, laboratory rats serum, AAS

\section{INTRODUCTION}

Chemical wastes such heavy metals in seawater ecososystems from anthrophogenic activities input such as industrial effluent, urban runoff, domestic activities etc were serious probleme for aquatic ecosystems (Skoog et al., 1994; Beiras et al., 2003 ; Catsiki et al., 2003; Liu and Kueh, 2005). Marine organisms such bivalve molluscs i.e. mussels have the ability to uptake heavy metals contamination from their aquatic environment. Marine mussels have been widely used as indicator organisms to assess the levels of coastal pollutions (Sze and $\mathrm{Li}, 2000)$. P.viridis has been known to be distributed at coastal or seawater region especially in archipel countries (Catsiki et al., 2003; Sze et al., 2003). Previously studies reported at several Southeasts country's coastal water (i.e. Malaysia, Hogkong, Thailand, India and Jakarta bay, Indonesia) that $\mathrm{Cu}, \mathrm{Zn}$ and $\mathrm{Cd}$ have been highly accumulated in the green mussels tissues (Yap et al., 2003, 2004) that can potentially being consumed by human via seafood market activities. Ingestion of heavy metals -contaminanted green mussels may cause disturbing neurosystem, harmful effets to tendon and absorb into bone, precipitate into body (Sze and Lee, 2000; Yap et al., 2004).
In broad area of Indonesia, $P$. viridis can be found easily in traditional market. In this study, we collected $P$. viridis from traditional market i.e. Ciroyom Bandung from which the mussels have been catched from Mundu water, Cirebon. Hence, our study was to determine the $\mathrm{Ni}, \mathrm{Cu}, \mathrm{Zn}$ and $\mathrm{Cd}$ concentration in the mussel and to determine their concentration in rat laboratory serum which orally feed with $P$. viridis.

\section{MATERIALS AND METHODS}

\section{Chemicals}

All solutions have used with pro analysis (p.a) quality such pure grade aquabidest (MiliQ, pure grade) anhydric metal standards powder, CuSO $4.5 \mathrm{H}_{2} \mathrm{O}, \mathrm{NiSO}_{4} \cdot 6 \mathrm{H}_{2} \mathrm{O}$, $\mathrm{ZnSO}_{4} .7 \mathrm{H}_{2} \mathrm{O}$ and $\mathrm{Cd}\left(\mathrm{NO}_{3}\right)_{2} \cdot 4 \mathrm{H}_{2} \mathrm{O}$ (Sigma Aldrich, $\mathrm{MO}, \mathrm{USA}$ ), $\mathrm{HNO}_{3} 65 \%$ (AnalaR grade, Merck, USA) as destruction solutions and $\mathrm{SnCl}_{2}$ as releasing agent (Merck USA), citric acid (Merck, USA), Whatman 42 and paper aluminium.

\section{Selection of acid digest solution}

$1000 \mathrm{ppm}$ each standar cation solution $\mathrm{Ni}, \mathrm{Cu}, \mathrm{Zn}$ and $\mathrm{Cd}$ were diluted in water to 5 ppm. $25 \mathrm{~mL}$ of each standard solution was 
pipetted and digested with different $\pm 5 \mathrm{~mL}$ (total volume) digest solvent, $\mathrm{HNO}_{3} 65 \%$ :water (1:1) and $\mathrm{HNO}_{3}$ p 65\% at different beaker. Their mixed and heated on hotplate Thermolyne MIRAK $^{\text {TM }}$ at $80^{\circ} \mathrm{C}$ for 1 hours. Then $15 \mathrm{~mL}$ every digest solvent was added then concentrated on hotplate at $140^{\circ} \mathrm{C}$ for 3 hours. After cooling in room temperature $\left(25^{\circ} \mathrm{C}\right)$, each digest solution with $\mathrm{HNO}_{3} 65 \%$ and $\mathrm{HNO}_{3}$ 65\%:water (1:1) with their metals were diluted at $50 \mathrm{~mL}$ water and standar solution mix of heavy metals $\mathrm{Ni}$, $\mathrm{Cu}, \mathrm{Zn}$ and $\mathrm{Cd}$ spiked to each digest solution then their added. We have made a preparation 4 sample artificiales replicats, $2 \mathrm{~mL}$ sample solutions were pipetted to each $10 \mathrm{~mL}$ glass. First glass contain the solvant (control) and another glass which have added mix cation standard solution $100 \mathrm{ppm}$ with volume simultant $25 \mu \mathrm{L}, 50 \mu \mathrm{L}, 100 \mu \mathrm{L}$. Each glasses were added $20 \mu \mathrm{L} \mathrm{HNO}_{3}(1: 1)$ to avoid hydrolisis effect.

\section{Preparation of mussels samples}

$\pm 3 \mathrm{~kg}$ wet mussels, $P$. viridis $(\approx 4.5-6.5$ $\mathrm{cm}$ lenght) were collected from traditional market. They were placed at room temperature before their treatment and all cockle of mussels have been removed from their tissues. Water residus was removed and filtered and evaporated at room temperature for 30 minutes while mussels were covered with paper aluminium (Liu and Kueh, 2005). wet tissues were blended meat chopper/ food processor AKEBONO $^{\mathrm{TM}}$ (Multi use-mincer JCW-45). Total of wet mass tissues were weighed by Ainsworth microbalance (Perkin elmer ADZZ), then collected into plastic bag and conserve in freezer $-10{ }^{\circ} \mathrm{C}$. wet tissue was placaed into crush alumina and dried at $105{ }^{\circ} \mathrm{C}$ for 1 hours to avoid and combusted in insenerator Thermolyne 8000 (Shimadzu, Japan) at $900{ }^{\circ} \mathrm{C}$ during 9 hours. Ash mass was weighed and stored at room temperature

\section{Dry digestion of mussels samples}

Ash of mussels c.a \pm 3 gram were weighed with analytical balance Ainsworth microbalance (Perkin elmer ADZZ). These samples were digested in $5 \mathrm{~mL} \mathrm{HNO}_{3}$ : water (1:1) sulution while heated $80{ }^{\circ} \mathrm{C}$ for 1 hours on the Hot Plate Thermolyne MIRAK ${ }^{\mathrm{TM}}$. Then added $15 \mathrm{~mL} \mathrm{HNO}_{3}$ :water (1:1) solutions while blend once time at temperature $140{ }^{\circ} \mathrm{C}$ for 3 hours. Digest sample solution was cooled at room temperature the filtered with whatman 45 to remove their residus, then filtrate was dilluted at $100 \mathrm{~mL}$ water.

\section{Digestion of blood rats laboratory serum}

Twelve white rats (Ratus norvegicus) which have similiar weight and ages (2-3 months, male) were orally feed of dry mussels with mix their meals every days. 3 rats were chossed as control. They were given orally feed only their meals usuals without mix by mussels samples. For 9 rats laboratory were given orally feeds of dry mussels by syringe. After 4,8 and 12 days, theirs blood were taken and placed in $1.5 \mathrm{~mL}$ Eppendorf tube and washed with citric sodium $38 \%$ as anticoagulant (Kosar et al., 2006). Blood rats samples were taken from their eyes (sinus orbitalis) (Smith and Mangkoewidjojo, 1988) then those samples were sentrifuged with microsentrifuge $22 \mathrm{~A}$ (hettic sentrifugenm Germany) at 11,000 rpm for 10 minute at $4{ }^{\circ} \mathrm{C}$ (Kosar et al., 2006). Their supernatants (blood serum) were taken from their residus. Each blood serums were digested with dillution acid $500 \mu \mathrm{L} \mathrm{HNO}_{3}$ : water (1:1) on hotplate $140{ }^{0} \mathrm{C}$ during 30 minute for denaturation their protein. After cooling at room temperature, blood serum was filtered with Whatman 42 also washed with sodium citric 3.8 $\%(w / v)$. Then each blood serum filtrate was dilluted in vial $10,00 \mathrm{~mL}$. $2 \mathrm{~mL}$ sample solutions were prepared and add with 100,00 ppm mix standard solutions with variation adding volume $(25 \mu \mathrm{L}, 50 \mu \mathrm{L}, 100 \mu \mathrm{L})$ and completed with 20 $\mu \mathrm{L} \mathrm{HNO}_{3}$ :water (1:1) as acid condition. Each serum solutin was analysed with Atomic Absorption Spectrometry.

\section{Atomic Absorption Spectrometry (AAS) analysis}

Atomic Absorption Spectrometry (AAS) $\left(\right.$ GBC $\left.^{\circledR} 902\right) /$ Perkin Elmer for analysis heavy metals in mussels with gas flow condition contain of air- acetilene and wave long $(\lambda)$ were measured $\mathrm{Ni}(\mathrm{II})(\lambda=232.0 \mathrm{~nm}), \mathrm{Zn}(\mathrm{II})(\lambda=213.9$ $\mathrm{nm}), \mathrm{Cu}(\mathrm{II})(\lambda=321.47 \mathrm{~nm})$ and $\mathrm{Cd}(\mathrm{II})(\lambda=228.8$ $\mathrm{nm})$.

\section{RESULT AND DISCUSSIONS}

\section{Selection of digest solutions}

One of analytical evaluation of comparing two different methods is a recoveries values. Artificial sample was a 4 mix individual standar solution $\mathrm{Ni}, \mathrm{Cu}, \mathrm{Zn}$ and $\mathrm{Cd}$ with concentration 5 $\mathrm{ppm}$. Recoveries values were obtained with two different digest solutions. Recovery for digest with $\mathrm{HNO}_{3}$ concentrated $65 \%$ ranged between $100-147 \%$. While the mixture of $\mathrm{HNO}_{3}$ /water (1/1) solution ranged $103-124 \%$, while Those results have shown at Table $\mathrm{I}$. 
Table 1. Recoveries percentage of two test (i). $\mathrm{HNO}_{3} 65 \%$ and (ii). $\mathrm{HNO}_{3} 65 \%$ : water (1:1). Each experiment has been conducted in duplicate

\begin{tabular}{ccccc}
\hline Solvant destuction & $\begin{array}{c}\mathrm{Ni} \\
(\%)\end{array}$ & $\begin{array}{c}\mathrm{Zn} \\
(\%)\end{array}$ & $\begin{array}{c}\mathrm{Cu} \\
(\%)\end{array}$ & $\begin{array}{c}\mathrm{Cd} \\
(\%)\end{array}$ \\
\hline $\mathrm{HNO}_{3}:$ water & 113 & 148 & 109 & 100 \\
$(1: 1) \mathrm{I}$ & & & & \\
$\mathrm{HNO}_{3}:$ water $(1: 1) \mathrm{II}$ & 97 & 101 & 108 & 105 \\
Average & $\mathbf{1 0 5}$ & $\mathbf{1 2 4}$ & $\mathbf{1 0 9}$ & $\mathbf{1 0 3}$ \\
$\mathrm{HNO}_{3} 65 \% \mathrm{I}$ & 116 & 184 & 90 & 143 \\
$\mathrm{HNO}_{3} 65 \% \mathrm{I}$ & 84 & 110 & 111 & 83 \\
Average & $\mathbf{1 0 0}$ & $\mathbf{1 4 7}$ & $\mathbf{1 0 1}$ & $\mathbf{1 1 3}$ \\
\hline
\end{tabular}

Both of digest solution can dissociate of heavy metal cations content in mix standards solutions. Their recovery values of $\mathrm{HNO}_{3}$ :water (1:1) were better than $\mathrm{HNO}_{3}$ concentrated $65 \%$ for digest acid solution.

\section{Determination of Heavy metals content in green mussels (Perna viridis)}

Mussels samples were formed ash using insenerator to avoid organic compounds in tyssus during oxidation process. We have obtained $13,2370 \mathrm{~g}$ ash mass from $87,1597 \mathrm{~g}$ dry mass samples. Digestion process has obtained two phase white ash powder under glass was removed the silica, sand from the solutions $(6,10)$. The results showed that the green mussels (Perna viridis) from tradtional market, Ciroyom Bandung have Zn(II) levels highest than other cause this cation as binding site of protein content in tyssus of green mussels (Yap et al., 2003, 2004) or from mussels habitat in seawater (Skoog et al., 1994; Huber, 1998). Heavy metal cations content in $P$. viridis were shown in Table2.

Table 2. Concentration of heavy metals cations in green mussels (Perna viridis) ( $\mu \mathrm{g} / \mathrm{g}$ ash mass)

\begin{tabular}{cccccc}
\hline Metals cations & $\mathrm{Mg}$ & $(\mathrm{ppm})$ & $\begin{array}{c}\mu \mathrm{g} / \mathrm{g}, \text { ash } \\
\text { mass }\end{array}$ & $\%$ mass $(\% \mathrm{w} / \mathrm{w})$ & Treshold limit \\
\hline $\mathrm{Ni}(\mathrm{II})$ & 3.50 & 0.70 & 1.17 & $2.33 \times 10^{-4}$ & 0.05 \\
$\mathrm{Cu}(\mathrm{II})$ & 20.18 & 4.03 & 6.73 & 0.01 & 0.02 \\
$\mathrm{Zn}(\mathrm{II})$ & 174 & 34.80 & 58 & 0.12 & 0.05 \\
$\mathrm{Cd}(\mathrm{II})$ & 4.91 & 0.98 & 1.64 & $3.27 \times 10^{-3}$ & 0.05 \\
\hline
\end{tabular}

Standard spike to samples at certains volumes $25 \mu \mathrm{L}, 50 \mu \mathrm{L}$ and $100 \mu \mathrm{L}$ were given high absorbance for $\mathrm{Zn}$ than another metal cations (Figure 1.)

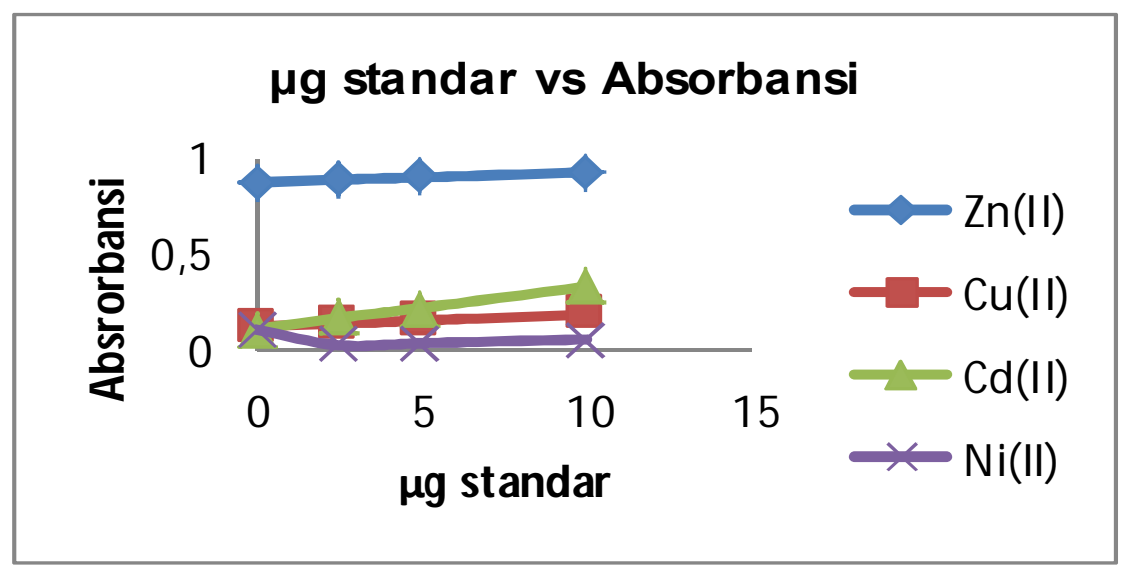

Figure 1. Calibration curve of ash mussel samples spiking method ( $\mu \mathrm{g}$ standar vs absorbance). 
From this results, the sequence of heavy metal content are $\mathrm{Ni}<\mathrm{Cd}<\mathrm{Cu}<\mathrm{Zn}$ with their confidence limit $\mathrm{Zn}$ '58 $\pm 10.76 \mu \mathrm{g} / \mathrm{g}$ in ash mass), $\mathrm{Cu}(6.73 \pm 3.04 \mu \mathrm{g} / \mathrm{g}), \mathrm{Cd}(1.64 \pm 0.57$ $\mu \mathrm{g} / \mathrm{g})$ and $\mathrm{Ni}(1.17 \pm 1,80 \mu \mathrm{g} / \mathrm{g})$, If the value of confidence limit is more than real value, it can influence of their accuracy (Skoog et al., 1994; Huber, 1998). Confidence limit used as standard microgram unit which added to sample solution. add standard mass vs absorbance used to determine this confidence limit. Less confidence limit make less of \% error with large of accuracy and precision.
Determination heavy metal in blood rat laboratory serum

The results showed high accumulation of heavy metal ( $\mathrm{Ni}, \mathrm{Cu}, \mathrm{Zn}$ and $\mathrm{Cd}$ ) in blood rats laboratory serum which have been orally feed for 4 days. However, after 2 days experimentation, Ni was not found in the blood serum. The accumulation of heavy metal in blood rats laboratory serum have been shown at Figure 2.

$\mu g / \mu L$ vs oral days

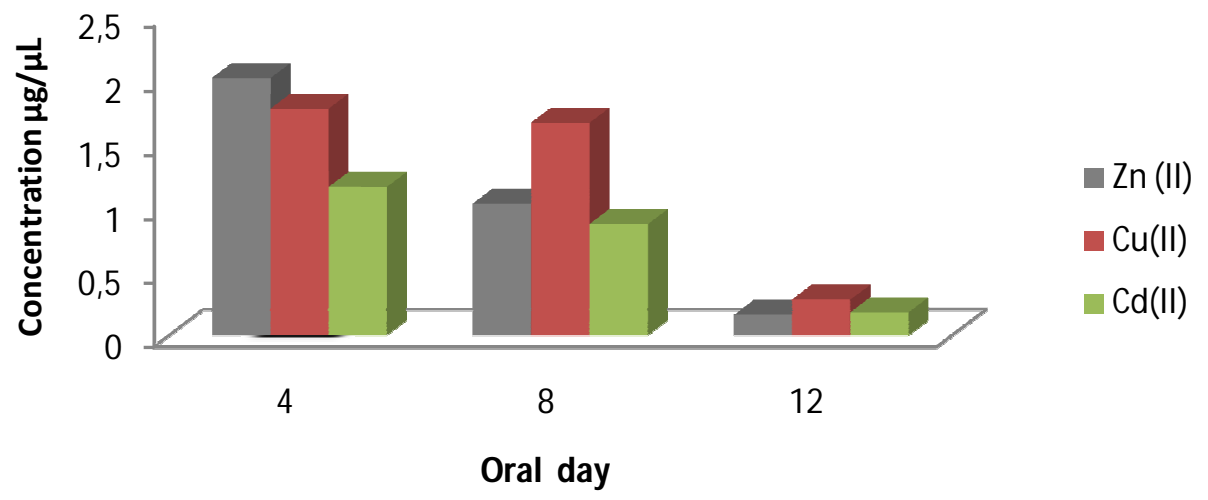

$\mu g / \mu L$ vs control days



Figure 2. Concentration of heavy metal cations on blood rats serum $(\mu \mathrm{g} / \mu \mathrm{L})$ for 4,8 and 12 days which orally feed by green mussels ( $\mu \mathrm{g} / \mu \mathrm{L}$ vs oral days) and without orally feed of green mussels $(\mu \mathrm{g} / \mu \mathrm{L}$ vs control days) 
Increasing concentrations of heavy metal in blood serum can be influenced by the metal content in the diet of rats, rats meals, the rats metabolic system and the content of metal cations contained in mussels samples. After 8 and 12 days, the heavy metal content have decreased. In control or blank (without orally feed of mussels, the metal content have founded but in small concentration. For orally feed by dry mussels, each serum, metal cations of $\mathrm{Zn}$ and $\mathrm{Cu}$ have potential accumulation comparing with their control. After 12 days, there were detected $\mathrm{Cu}$ level ranged from 0.37$1.22 \mu \mathrm{g} / \mu \mathrm{L}$ and $\mathrm{Zn}$ level ranged from 0.6 to $2.09 \mu \mathrm{g} / \mu \mathrm{L}$,. Otherwise, $\mathrm{Ni}$ and $\mathrm{Cd}$ level have not found in both blood rats serum treatment and only Cd was found in very small extent in 12 days.

\section{CONCLUSION}

The acid digest solution $\mathrm{HNO}_{3}$ : water (1:1) was choossed to digest green mussels samples with dry digestion methods. This solution has recovery ranged near $100 \%$ (103$124 \%$ ). The sequences of heavy metal in green mussels tissues were $\mathrm{Ni}<\mathrm{Cd}<\mathrm{Cu}<\mathrm{Zn}$. Determination of heavy metal in blood rats serum showed the impact of the $\mathrm{Cu}, \mathrm{Zn}$ and $\mathrm{Cd}$ accumulation for each rats experiment which orally feed of green mussels during 4,8 and 12 days while $\mathrm{Ni}$ was not detected in rats laboratory blood serum.

\section{REFERENCES}

Beiras, R., Fernandez, N., Bellas, J., Besada, A., Gonzalez-Quijano, A., Nunes, T., 2003. Integrative assessment of marine pollution in Galician estuaries using sediment chemistry, mussel bioaccumulation and embryo-larval toxicity bioassays. Chemosphere 52, 1209-1224.

Catsiki, V.A., Hatzianestis, I., Rigas, F., 2003, Distribution of metals and organic contaminants in mussels from Thermaikos Gulf. Global Nest: The International Journal 5,119-126.

Huber, L. 1998, Validation of Analytical Methods: Review and Strategy, Lab compliance Agilent Technology, 14-15.

Kosar, F., Sahin, I., Taskapan, C., Kucukbay, Z., Gullu, H., Taskapan, H., Chereli, S.2006, Trace element status ( $\mathrm{Zn}, \mathrm{Se}$, $\mathrm{Cu}$ ) in heart failure. Anadolu Kardiyol Dergep 6. 216-220.
Liu, J.H. and Kueh, C.S.W., 2005, Biomonitoring of heavy metals and trace organics using the interdial mussel Perna viridis in Hongkong coastals waters. Marine Pollution Bulletin 51, 857-875.

Skoog, A.D., Holler, F.J, Nieman, T.A. 1994, Fundamental of Instrumental Analysis, eight edition, Saunders College Publishing America. 110-118 (Statistical treatment of Random Error), 143 (Convidence intervals).

Yap, C.K., Ismail, A., Tan, S.G. 2004, Heavy metal (Cd, $\mathrm{Cu}, \mathrm{Pb}$, and $\mathrm{Zn}$ ) concentrations in the green-lipped mussel Perna viridis (Linnaeus) collected from some wild and aquacultural sites in the west coast of Peninsular Malaysia. Journal of Food Chemistry 84, 569-575.

Yap,C.K., Ismail, A., Tan, S.G., Omar, H. 2003, Accumulation, depuration and distribution of cadmium and zinc in the green-lipped mussel Perna viridis (Linnaeus) under laboratory conditions. Journal Hydrobiologia 498. 151-160

Sze, P.W.C., Lee S.Y. 2000, Effects of chronic copper exposure on the green mussel Perna viridis. Marine Biology 137.379392

Smith B.V.Sc., J.B. Mangkoewidjojo, S. (1988), Pemeliharaan, Pembiakan dan Penggunaan hewan percobaan di daerah tropis. Penerbit Universitas Indonesia(UI-Press), h: 30-31, 33-35. 